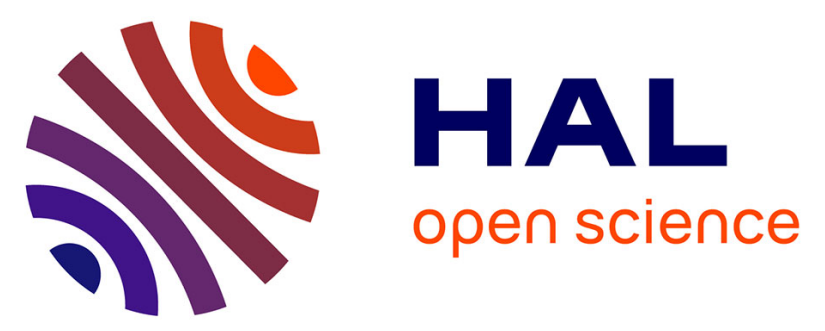

\title{
New pollen evidence from Nariani (Georgia) for delayed postglacial forest expansion in the South Caucasus
}

Erwan Messager, Sébastien Nomade, Bruno Wilhelm, Sébastien Joannin, Vincent Scao, Ulrich von Grafenstein, Inga Martkoplishvili, Vincent Ollivier, Ana Mgeladze, Jean-Pascal Dumoulin, et al.

\section{To cite this version:}

Erwan Messager, Sébastien Nomade, Bruno Wilhelm, Sébastien Joannin, Vincent Scao, et al.. New pollen evidence from Nariani (Georgia) for delayed postglacial forest expansion in the South Caucasus. Quaternary Research, 2017, 87 (1), pp.121 - 132. 10.1017/qua.2016.3 . hal-01766652

\section{HAL Id: hal-01766652 \\ https://hal.science/hal-01766652}

Submitted on 19 Feb 2021

HAL is a multi-disciplinary open access archive for the deposit and dissemination of scientific research documents, whether they are published or not. The documents may come from teaching and research institutions in France or abroad, or from public or private research centers.
L'archive ouverte pluridisciplinaire HAL, est destinée au dépôt et à la diffusion de documents scientifiques de niveau recherche, publiés ou non, émanant des établissements d'enseignement et de recherche français ou étrangers, des laboratoires publics ou privés.

\section{(ㅇ)(1) $\$$}

Distributed under a Creative Commons Attribution - NonCommercial - NoDerivatives| 4.0 


\title{
New pollen evidence from Nariani (Georgia) for delayed postglacial forest expansion in the South Caucasus
}

\author{
Erwan Messager $^{\mathrm{a} *}$, Sébastien Nomade ${ }^{\mathrm{b}}$, Bruno Wilhelm ${ }^{\mathrm{c}}$, Sébastien Joannin ${ }^{\mathrm{d}}$, Vincent Scao ${ }^{\mathrm{b}}$, Ulrich Von Grafenstein ${ }^{\mathrm{b}}$, \\ Inga Martkoplishvili ${ }^{e}, \mathrm{f}$, Vincent Ollivier ${ }^{\mathrm{g}}$, Ana Mgeladze ${ }^{\mathrm{f}}$, Jean-Pascal Dumoulin ${ }^{\mathrm{h}}$, Arnaud Mazuy ${ }^{\mathrm{i}}$, Soumaya Belmecheri $^{\mathrm{j}}$, \\ David Lordkipanidze ${ }^{\mathrm{f}}$ \\ ${ }^{a}$ CNRS UMR 5204 EDYTEM, Campus Technolac Savoie Mont Blanc University, 73376 Le Bourget-du-Lac, France

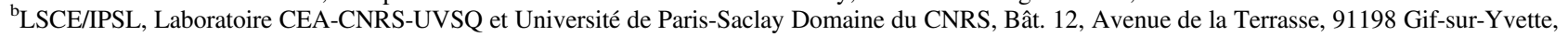 \\ France \\ ${ }^{c}$ University Grenoble Alpes, LTHE, 38000 Grenoble, France \\ ${ }^{\mathrm{d}}$ ISEM, UMR 5554 CNRS, Université de Montpellier, EPHE, IRD 226, CIRAD, 34095 Montpellier, France \\ ${ }^{\mathrm{e}}$ Ilia State University, 3/5 Cholokashvili St., 0162 Tbilisi, Georgia \\ ${ }_{\mathrm{f}}^{\mathrm{f}}$ Georgian National Museum, 3, Rustaveli Avenue, 0105 Tbilisi, Georgia \\ ${ }^{g}$ Aix Marseille Université, CNRS, MCC, LAMPEA UMR 7269, 13094 Aix-en-Provence, France \\ ${ }^{\text {h}}$ UMS 2572, Laboratoire de Mesure du Carbone 14, CEA Saclay, 91191 Gif-sur-Yvette, France \\ ${ }^{i}$ UMR 7264, CEPAM-CNRS Nice Université, Campus SJA3, 06357 Nice Cedex 4, France \\ ${ }^{\mathrm{j}}$ Laboratory of Tree-Ring Research, 1215 East Lowell Street, Tucson, AZ 85721, United States
}

(ReCEIVED April 21 2016; ACCEPTEd October 14 2016)

\begin{abstract}
The nature and timing of environmental changes throughout the last glacial-interglacial transition in the South Caucasus, and more widely in eastern Europe, are still not fully understood. According to certain pollen records, forest expansion occurred in many areas several millennia after what is considered worldwide as the onset of the Holocene. The current problem we face is that the time lag in forest expansion varies from one sequence to another, sometimes with no delay at all. Moreover, the potential forcing/controlling factors behind this complex pattern, contrary to the almost synchronous global Holocene warming, are still a matter for debate. Accordingly, we revisit the issue of forest expansion through vegetation history obtained in the South Caucasus using a new pollen record, retrieved from the Nariani paleolake (South Georgia). These data attest to a steppic phase, initially dominated by Amaranthaceae-Chenopodiaceae (12,700-10,500 cal yr BP), then by Poaceae $(10,500-9000 \mathrm{cal}$ yr BP), culminating with a more forested phase (9000-5000 cal yr BP). Although some palaeoclimatic regional reconstructions show a wet early Holocene, we interpret the delay in forest expansion recorded in Nariani (2500 years) as the result of reduced spring precipitation, which would have limited forest development at that time.
\end{abstract}

Keywords: South Caucasus; Paleolake; Forest expansion; Early Holocene

\section{INTRODUCTION}

Within the South Caucasus (equivalent of "Transcaucasia"), previous pollen studies have already been undertaken (Margalitadze, 1971, 1977, 1995; Kvavadze and Connor, 2005; de Klerk et al., 2009; Connor, 2011; Messager et al., 2013; Joannin et al., 2014; Leroyer et al., 2016). These studies have delivered quite different vegetation histories. The timing of postglacial forest expansion appears to vary between sites and is quite different from the pattern observed in western Eurasia. In fact, the major warming occurring at the transition

*Corresponding author at: CNRS UMR 5204 EDYTEM, Campus Technolac Savoie Mont Blanc University, 73376 Le Bourget du Lac, France. E-mail address: erwan.messager@univ-smb.fr between the Younger Dryas and the early Holocene (Von Grafenstein et al., 1999; Rasmussen et al., 2006; Svensson et al., 2006), marked in western Eurasia by the expansion of temperate trees (Huntley and Birks, 1983; Wick, 2000), is still associated with a steppic environment in several records from the South Caucasus (Margalitadze, 1995; Messager et al., 2013; Joannin et al., 2014; Leroyer et al., 2016). Sites located in the eastern part of the region record later forest expansion than sites located in the western part (i.e., on the shore of the Black Sea; Kvavadze and Connor, 2005). Among the records from the eastern region, the pollen sequence from Lake Paravani (central South Caucasus, Javakheti Plateau) has revealed a delayed forest expansion, starting between 9000 and $8000 \mathrm{cal} \mathrm{yr} \mathrm{BP}$, almost 3 millennia after the onset of Holocene warming (Messager et al., 2013). 
Depending on the sequence in the region, the major postglacial ecological shift becomes evident only 2 to 5 millennia after the transition between the Younger Dryas and the early Holocene (ca. 11,650 cal yr BP).

Some authors suggest that the delay between the Younger Dryas-Holocene warming and forest expansion may be explained by a period of aridity (Stefanova and Ammann, 2003; Wick et al., 2003; Wright et al., 2003; Shumilovskikh et al., 2012; Connor et al., 2013). However, geochemical and isotopic indicators from several lakes in Turkey suggest increasing annual precipitation during the early Holocene (Lemcke and Sturm, 1997; Roberts et al., 2001; Wick et al., 2003; Jones et al., 2007; Dean et al., 2015). The reasons for these differences among sites and regions are still unclear. In order to obtain a more comprehensive overview of the vegetation dynamics during the Younger Dryas-Holocene transition in the South Caucasus, new sedimentary sequences (Nariani, Saghamo, Kartsakhi, and Tabatskuri) have been cored on the Javakheti Plateau (southern Georgia). This article presents the initial results from this new coring program, consisting of a $180 \mathrm{~cm}$ sequence from the Nariani wetland. A previous pollen analysis was carried out in this wetland by Margalitadze (1977) on an undated sequence of $7.75 \mathrm{~m}$.

\section{REGIONAL AND LOCAL SETTING}

The Nariani wetland $\left(41^{\circ} 41^{\prime} \mathrm{N}, 43^{\circ} 40^{\prime} \mathrm{E}\right.$; 2058 meters above sea level [m asl]) corresponds to a completely filled paleolake (area of $\sim 10 \mathrm{~km}^{2}$ ) that evolved as extensive marshland (Fig. 1). The wetland lies adjacent to the Ktsia River and is located close to Lake Tabatskuri (Fig. 2) on the Javakheti Plateau. This plateau, located in the central part of the South Caucasus, is composed of basaltic-andesitic lavas that erupted during the Late Pliocene to late Pleistocene (Lebedev et al., 2008; Nomade et al., 2016). The Javakheti region possesses the largest number of lakes and marshes within the Caucasus (Matcharashvili et al., 2004). Inherited glacial morphologies and formations occur on the Javakheti Plateau, but today there are no glaciers present. The climate of the Javakheti Plateau is continental with long, cold winters and short, cool summers. The mean annual temperature is approximately $5.3^{\circ} \mathrm{C}$, and the annual precipitation rate is about $500-600 \mathrm{~mm}$ with a maximum in late spring and early summer and a minimum in January (Matcharashvili et al., 2004). Today, the Javakheti Plateau is covered by herbaceous vegetation (Fig. 2) and surrounded by various types of forest (Nakhutrishvili, 1999). The most widely distributed vegetation community is mountain steppe, dominated by grasses (Poaceae family, e.g., Festuca spp. or Stipa spp.). Forest communities are mostly absent from the plateau, and only two small areas of subalpine forest still exist: a patch of Betula litwinowii, Populus tremula, and Sorbus aucuparia, located on the eastern part of Lake Kartsakhi (Matcharashvili et al., 2004); and a patch of dwarf beech forest located on the side of Mt. Tavkvetili (Arabuli et al., 2008). Although the Javakheti Plateau is steppic, the Bakuriani region, located only $20 \mathrm{~km}$ northwest of the Nariani wetland (Fig. 2), is covered by different types of mountain forest. These forests are composed of beech (Fagus orientalis)spruce (Picea orientalis) and fir (Abies nordmanniana)-spruce formations. Open woodland (called Krummholz), characterized by a mix of tall grassland, forbs, scrubs, and trees such as birch (Betula litwinowii), and maple (Acer trautvetteri)), occupies the northern border of the Plateau (Fig. 2).

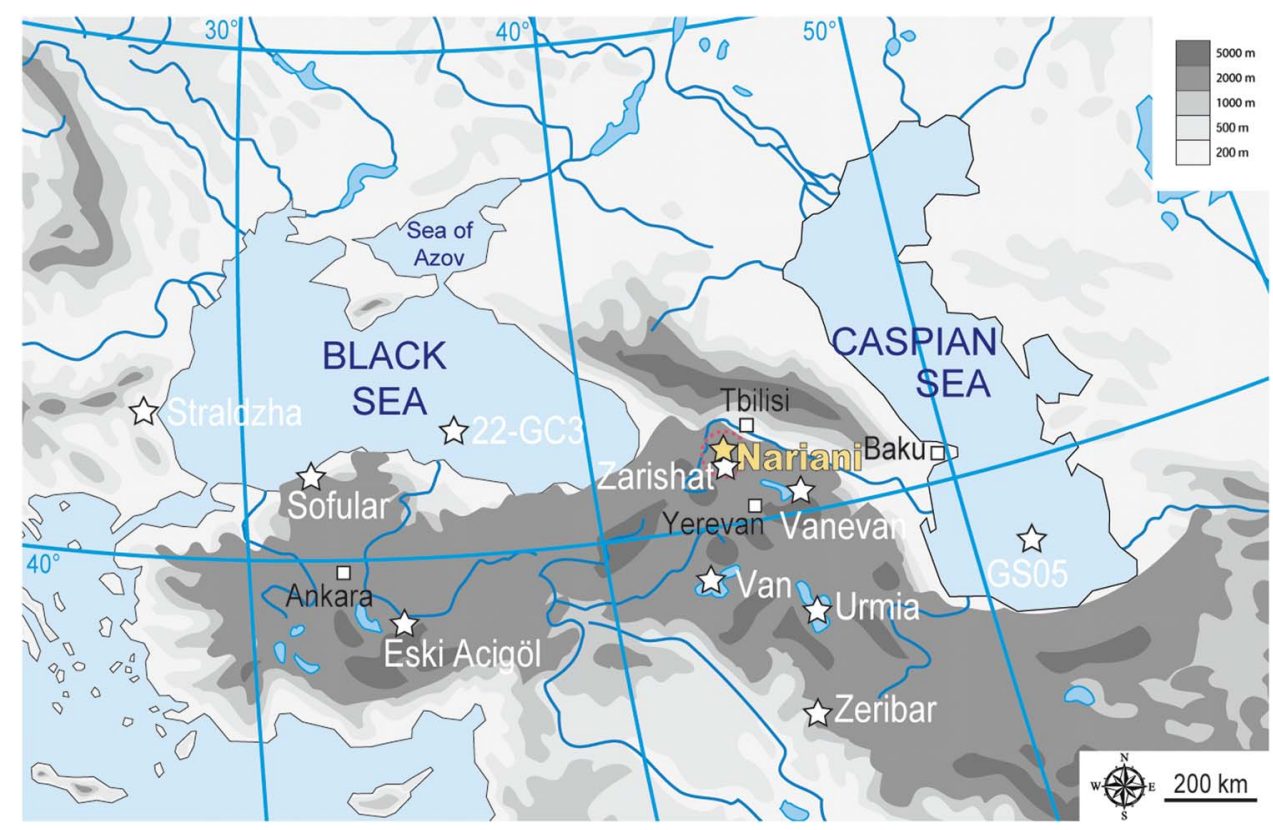

Figure 1. (color online) Physiographic map of the region showing the location of the Javakheti Plateau (dotted circle), Nariani and pollen records discussed in the text (stars). Adapted from GeoAtlas (http://www.geoatlas.fr/). 


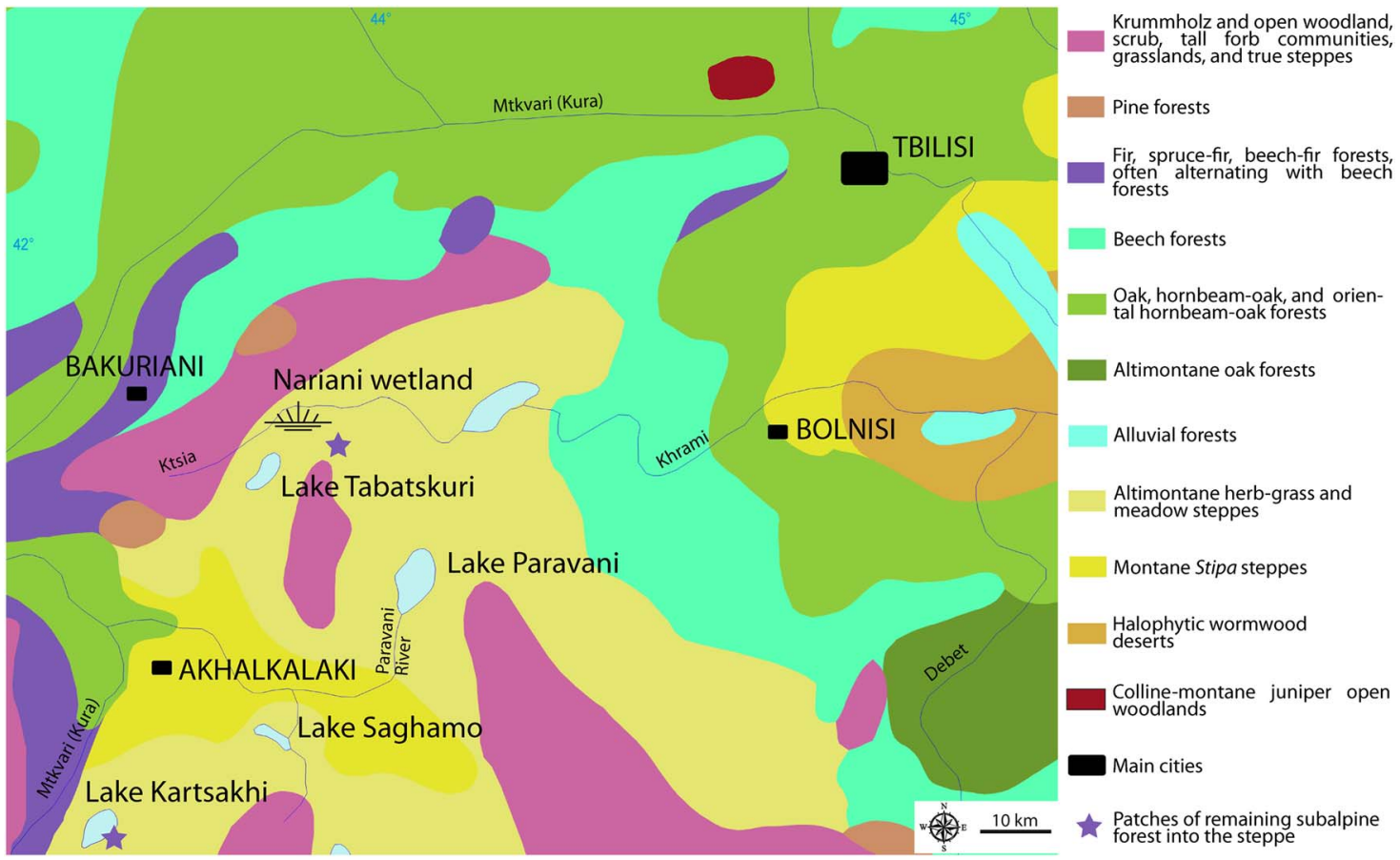

Figure 2. (color online) Vegetation map of the region (prepared using EuroVegMap software; Bohn et al., 2000). The stars represent the two small areas of natural subalpine forest (Lake Kartsakhi and Mt. Tavkvetili).

\section{MATERIALS AND METHODS}

\section{Core site and chronology}

A core $180 \mathrm{~cm}$ long, NAR-10, was retrieved using a Russian corer in the eastern part of the Nariani wetland. The core chronology is based on nine AMS (accelerator mass spectrometry) ${ }^{14} \mathrm{C}$ ages determined on bulk sediment (Table 1). Clam v2 (Blaauw, 2010), written for the open-source statistical software $\mathrm{R}$, was used to calibrate the ${ }^{14} \mathrm{C}$ ages with the IntCal13 calibration curve (Reimer et al., 2013) and to construct an age-depth model. The top of the core $(30-0 \mathrm{~cm})$ was not studied because it was impacted upon by modern soil.

\section{Pollen analysis}

Forty-three samples were taken at $2-6 \mathrm{~cm}$ intervals for the purposes of pollen analyses. For each sample, 1-2 $\mathrm{g}$ of sediment was processed following standard methods in palynology using $\mathrm{HCl}, \mathrm{KOH}$ baths (Faegri and Iversen, 1989), and heavy liquid flotation (Girard and RenaultMiskovsky, 1969; Goeury and Beaulieu, 1979). If significant amounts of silica particles remained, a HF bath was used. After treatment, the residue was suspended in glycerol, mounted onto microscope slides and counted using Zeiss standard and Leica DM 1000 microscopes. Pollen grains were identified using atlases of European and Mediterranean pollen types (Reille, 1992; Beug, 2004). The pollen concentration ranges from 50,000 to 100,000 grains $\mathrm{g}^{-1}$ in the first part of the sequence (from 180 to $140 \mathrm{~cm}$ ), and from 150,000 to 300,000 pollen grains $\mathrm{g}^{-1}$ in the second part (from 140 to $30 \mathrm{~cm}$ ) of the sequence. The pollen sum (reported in the diagram) was higher than 300 in most of the samples. Percentage calculation was based on the total terrestrial pollen (arboreal pollen [AP] + nonarboreal pollen), excluding Cyperaceae and moss

Table 1. List of AMS (accelerator mass spectrometry) ${ }^{14} \mathrm{C}$ dates from Nariani core NAR 10 . The ${ }^{14} \mathrm{C}$ ages were calibrated using IntCal13 (Reimer et al., 2013). Asterisks indicate the rejected ages.

\begin{tabular}{|c|c|c|c|c|c|c|c|}
\hline Laboratory code & Sample & Depth (cm) & Nature & $\mathrm{mg} \mathrm{C}$ & $\delta^{13} \mathrm{C}$ & ${ }^{14} \mathrm{C}$ yr BP & Age (cal yr BP) \\
\hline SacA 24019 & C1 30-31 & 30.5 & Bulk & 0.43 & -28.90 & $4505 \pm 35$ & $5046-5300$ \\
\hline SacA 24020 & C2 60-61 & 60.5 & Bulk & 0.77 & -27.40 & $6845 \pm 35$ & $7608-7753$ \\
\hline SacA 28596 & C1 $84-85$ & 84.5 & Bulk & 0.96 & -27.0 & $8400 \pm 40$ & $9305-9500$ \\
\hline SacA 28597 & C1 92-93 & 92.5 & Bulk & 1.12 & -28.3 & $9380 \pm 45$ & $10,502-10,717^{*}$ \\
\hline SacA 24021 & C2 95-96 & 95.5 & Bulk & 0.73 & -29.60 & $3570 \pm 30$ & $3730-3970 *$ \\
\hline SacA 28598 & C2 110-111 & 1105 & Bulk & 0.95 & -23.9 & $8905 \pm 45$ & $9835-10,198$ \\
\hline SacA 28599 & C1 131-132 & 131.5 & Bulk & 1.14 & -25.3 & $9930 \pm 45$ & $11,236-11,601$ \\
\hline SacA 24022 & C1 140-141 & 140.5 & Bulk & 0.40 & -29.00 & $10,460 \pm 45$ & $12,071-12,516$ \\
\hline SacA 24023 & C1 170-171 & 170.5 & Bulk & 0.23 & -24.40 & $10,740 \pm 50$ & $12,603-12,738$ \\
\hline
\end{tabular}


and Pteridophyte spores. The diagram was produced using Gpalwin software (Goeury, 1997).

\section{Loss on ignition}

Loss on ignition (LOI) analyses were carried out to estimate the organic content of the sediment, following the procedure used by Heiri et al. (2001). Forty samples were collected at $1-3 \mathrm{~cm}$ intervals, and these were then dried. Because organic matter is oxidized to carbon dioxide and ash at temperatures between about $200^{\circ} \mathrm{C}$ and $500^{\circ} \mathrm{C}$, the record of sample weights before and after heating (ignition at $550^{\circ} \mathrm{C}$ during $5 \mathrm{~h}$ ) allows us to estimate the weight of the organic content. The heating of several test samples to $950^{\circ} \mathrm{C}$ (for a period of $2 \mathrm{~h}$ ) in order to estimate the carbonate content yielded so negligible a weight loss $(<1 \%)$ that this step of the process was abandoned.

\section{RESULTS AND INTERPRETATION}

\section{Chronology, lithology, and LOI}

Turning our attention to the age-depth model (Fig. 3), one date $\left(3570 \pm 30{ }^{14} \mathrm{C}\right.$ yr BP) from a depth of $95.5 \mathrm{~cm}$ clearly appeared too young and therefore was rejected. The date at a depth of $93-92 \mathrm{~cm}$ was also rejected in the age-depth model because it turned out to be too old. Sedimentation rate (SR) is higher $\left(0.88 \mathrm{~mm} \mathrm{yr}^{-1}\right)$ at the base of the sequence $(180-141 \mathrm{~cm})$ and then decreases along the sequence to reach $0.05 \mathrm{~mm} \mathrm{yr}^{-1}$, except in the middle part (close to $100 \mathrm{~cm}$ ), where it displays a slight rise up to $0.33 \mathrm{~mm} \mathrm{yr}^{-1}$.
Table 2. List of units with their lithology, sedimentation rate (SR), and loss on ignition (LOI). NC, not calculated.

\begin{tabular}{lclcc}
\hline \hline Unit & Depth $(\mathrm{cm})$ & Description & $\begin{array}{c}\text { SR } \\
\left(\mathrm{mm} \mathrm{yr}^{-1}\right)\end{array}$ & $\begin{array}{c}\text { LOI } \\
(\%)\end{array}$ \\
\hline 1 & $180-155.3$ & Compact gray sandy silt & $0.88-0.47$ & $10-13$ \\
2 & $155.3-140.7$ & Grayish-green silt & $0.47-0.20$ & $17-19$ \\
3 & $140.7-90$ & Brown gyttja & $0.33-0.16$ & $23-39$ \\
4 & $90-28.5$ & Brown and dark-brown & $0.28-0.07$ & $46-16$ \\
& \multicolumn{4}{c}{ gyttja } \\
5 & $28.5-0$ & Dark-brown gyttja, crossed & $\mathrm{NC}$ & $\mathrm{NC}$ \\
& \multicolumn{4}{c}{ by herbaceous roots } \\
\hline \hline
\end{tabular}

The stratigraphy of the Nariani sequence was subdivided into five different units from the base to the top of the sequence according to the sediment color (Table 2).

The LOI results $\left(550^{\circ} \mathrm{C}\right)$ accord well with the sediment description. The compact, gray to grayish-green sediment at the base (units 1 and 2) has lower organic content $(10 \%-19 \%)$, whereas the brown upper part features higher $(16 \%-46 \%)$ organic content (Fig. 3). In the lowest deposit (unit 1), the lower organic matter input may reflect limited productivity in the former lake water and poorly developed soils in the catchment area. The LOI tests at $950^{\circ} \mathrm{C}$ did not reveal significant carbonate content in the Nariani sediment.

\section{Pollen results}

Results of the pollen analyses are presented in the pollen diagram (Fig. 4). Local pollen assemblage zones (LPAZs) have been defined (Birks and Birks, 1980) using the CONISS

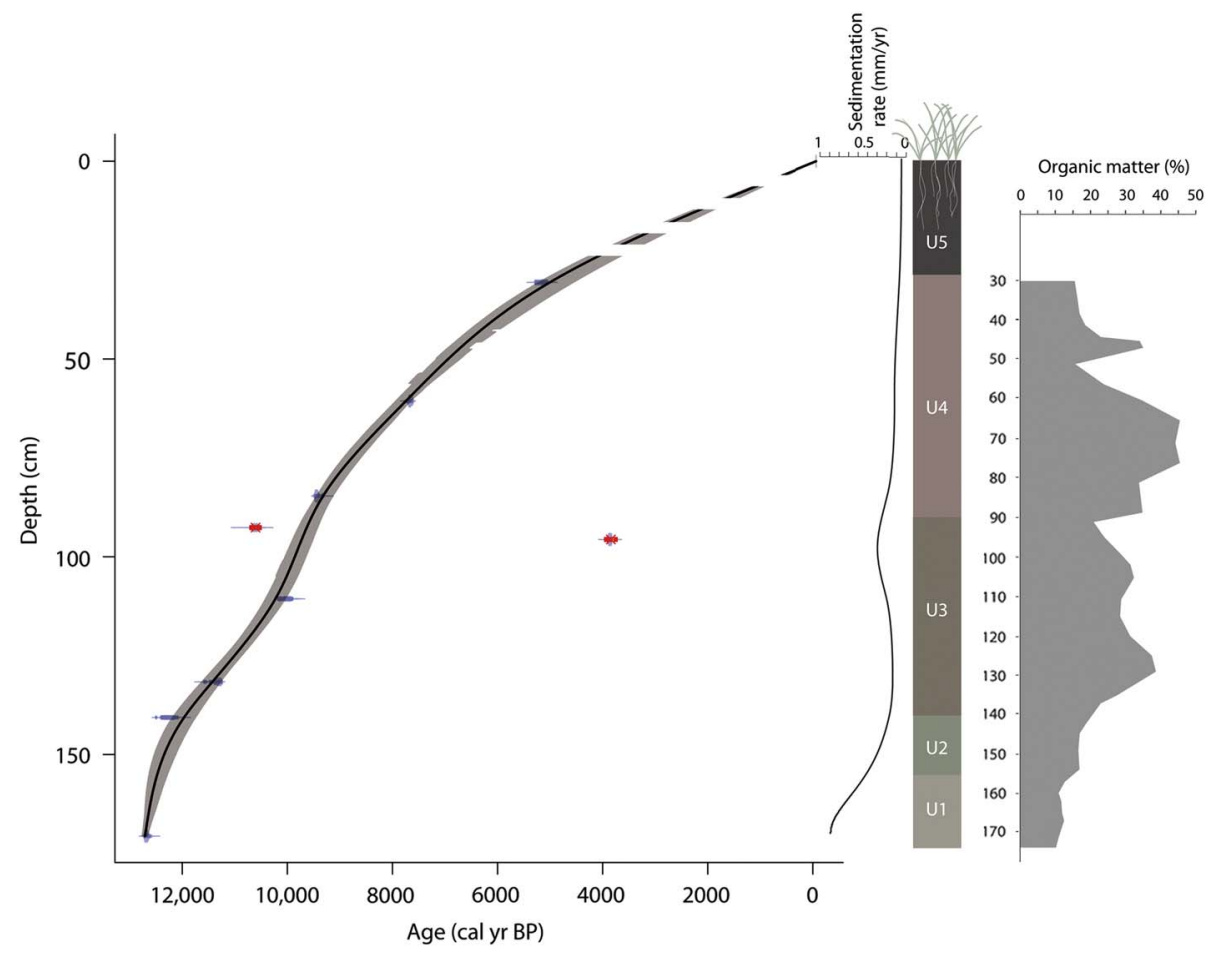

Figure 3. (color online) Age-depth model, lithology, and organic matter content of the Nariani sequence. Rejected ages are indicated in red. 


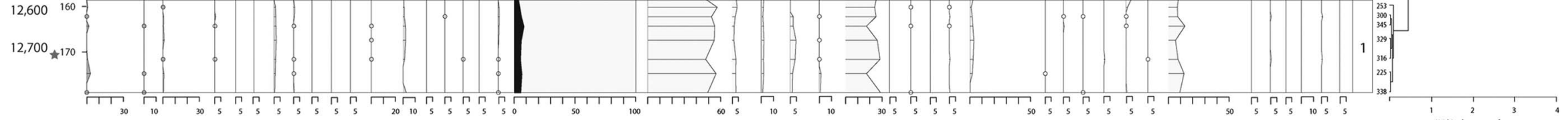

Figure 4. Diagram of selected pollen data from Nariani versus age in cal ka BP. AP, arboreal pollen; LPAZ, local pollen assemblage zones; NAP, nonarboreal pollen. Pollen values lower than $0.5 \%$ are represented by dots. Gray stars correspond to rejected ${ }^{14} \mathrm{C}$ dates. 
method (Grimm, 1987). Five main LPAZs have been identified in the Nariani pollen record:

- LPAZ 1 (depth $178-158 \mathrm{~cm}$ ) is characterized by a predominance of herbaceous pollen taxa. Pollen assemblages are dominated by Amaranthaceae-Chenopodiaceae (40\%-57\%), Artemisia (17\%-28\%), and Poaceae $(6 \%-13 \%)$, indicating open vegetation. Other herbaceous families, such as Alismataceae, Apiaceae, and Asteraceae, are well represented. The xeric and steppic taxon, Ephedra distachya t., is frequently identified. Tree and shrub pollen grains are scarce. Betula, Quercus, Fagus, and Pinus are recorded in LPAZ 1, but the AP values (sum of tree pollen grains) never exceed $8 \%$. The end of this zone is marked by a decrease in AmaranthaceaeChenopodiaceae.

- LPAZ 2 (depth $158-117 \mathrm{~cm}$ ) is characterized by relatively stable values for Amaranthaceae-Chenopodiaceae, around 30\%. Among herbaceous taxa, Artemisia tends to decrease whereas the Poaceae gradually increase. The environment is still steppic (low AP values). This phase is marked by the significant occurrence of Myriophyllum pollen grains. Myriophyllum is an aquatic taxon, living submerged in water, and its temporary abundance might reflect the presence of permanent water. A very slight increase in tree pollen grains is recorded at the end of this phase (from $10 \%$ to $15 \%$ ).

- LPAZ 3 (depth $117-81 \mathrm{~cm}$ ) is characterized by a significant decrease in Amaranthaceae-Chenopodiaceae and Artemisia values, whereas Poaceae values rise significantly, from $27 \%$ to more than $58 \%$. The AP values are stable (between 10\% and 15\%) and increase at the end of the zone (up to 23\%). Quercus and Fagus are better represented than in the previous phases. The end of this zone is marked by increasing percentages of Cyperaceae, probably reflecting the beginning of the filling of the lake. A decrease in Poaceae and Amaranthaceae-Chenopodiaceae values is recorded at the same time. The end of LPAZ 3 is also characterized by a weak increase in AP values (exceeding 20\%).

- LPAZ 4 (depth $81-69 \mathrm{~cm}$ ) is characterized by a simultaneous and significant expansion of Abies and Pinus, suggesting a rapid colonization by coniferous trees in the environs of Nariani. Among the deciduous trees, Fagus displays the same rise (up to 13\%) as the coniferous trees but is lower in intensity. Quercus shows a slightly increasing pollen curve (4\%-9\%). The tree taxon Ulmus/Zelkova displays a continuous curve, and Corylus a semicontinuous curve. AP values reach $65 \%$ in this phase. The rise in Cyperaceae, initiated in the previous phase, continues. Poaceae and AmaranthaceaeChenopodiaceae record a decline within this zone. The end of this phase is characterized by a clear decrease of Pinus and a slight decrease of deciduous trees such as beech (Fagus) and oak (Quercus).

- LPAZ 5 (depth $69-30 \mathrm{~cm}$ ) is characterized by almost constant tree pollen values (AP), reflecting relative stability in the contributions of the different tree taxa. Spruce (Picea), which was sporadically present in the

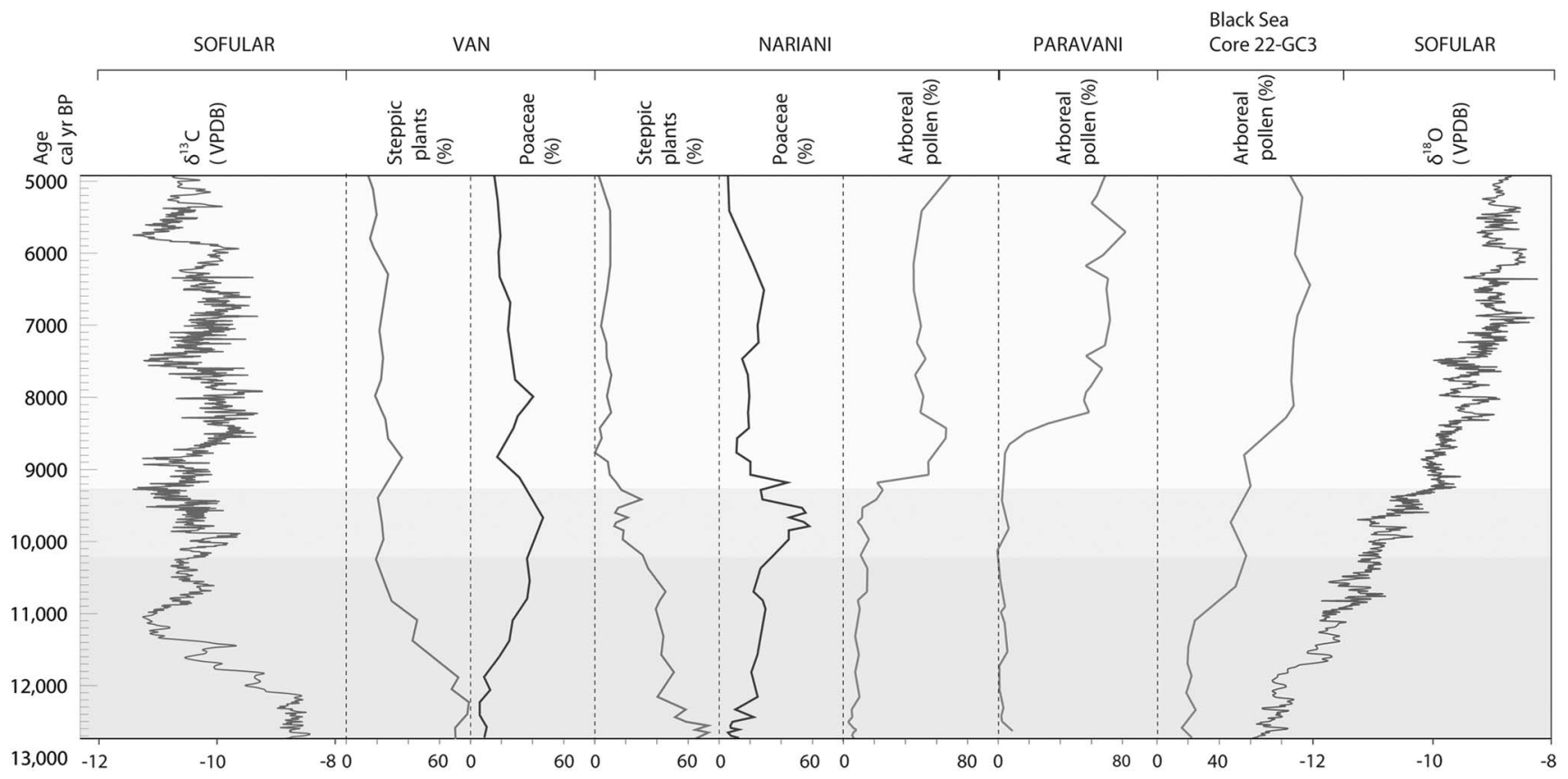

Figure 5. Comparison of several records from the Black Sea region, showing isotopic data from Sofular stalagmites (Fleitmann et al., 2009) and pollen data from Lake Van (Wick et al., 2003), Nariani (this study), Lake Paravani (Messager et al., 2013), and Black Sea core 22-GC3 (Shumilovskikh et al., 2012). Except for Paravani and Nariani, the pollen curves are based on pollen data from the European Pollen Database (http://www.europeanpollendatabase.net), VPDB (International reference standard "Vienna Pee Dee Belemnite"). 
previous phase, occurs in greater quantities in this zone. Among herbaceous pollen taxa, the main relevant change is observed in Cyperaceae values, which increase significantly at the end of the phase. The Poaceae values decrease at the same time.

\section{DISCUSSION}

\section{Vegetation history inferred from the Nariani pollen record}

\section{A two-step steppic phase}

The pollen record for the lower Nariani deposits (LPAZs 1 and 2) indicates a steppic and arid environment from 12,700 to $10,500 \mathrm{cal}$ yr BP. For the first part of this phase (LPAZ 1, $12,700-12,500$ cal yr BP), Amaranthaceae-Chenopodiaceae and Artemisia together represent more than $70 \%$ of the pollen assemblages. Poaceae and other herbaceous plants, such as Asteraceae and Apiaceae, are also observed. Steppic conditions are reflected by the frequent occurrence of the well-dispersed pollen of Ephedra (Connor, 2011). Such vegetation, dominated by Amaranthaceae-Chenopodiaceae, is characteristic of glacial phases recorded in the two regional long sequences: Lake Urmia (Djamali et al., 2008) and Lake Van (Wick et al., 2003; Litt et al., 2014). Similarly, a dry steppe is also observed during the Younger Dryas at Lake Paravani (Messager et al., 2013). In the eastern Mediterranean and the Middle East, the Younger Dryas event is marked by increasing climate aridity (Bottema, 1995; Wick et al., 2003; Wright et al., 2003).

In the second part of this steppic phase (LPAZ 2, 12,50010,500 cal yr BP; see Fig. 4), Artemisia and AmaranthaceaeChenopodiaceae are still dominant, but their proportions decrease slightly, possibly suggesting more humid conditions. Like in the Paravani sequence, the steppic phase spans the Younger Dryas, but also part of the early Holocene. In Lake Aligol (1540 m asl, Tsalka Plateau), a short-lived pioneer phase, composed of Corylus and Betula, was recorded between 12,000 and 11,000 cal yr BP (Connor and Sagona, 2007). However, neither the Paravani nor Nariani sequences, located at higher altitudes, display this phase. The abundance of Myriophyllum at this time can be interpreted as a sign of the presence of permanent water. However, because Myriophyllum can grow in a wide range of water depths (from a few decimeters to 7-8 m), it is difficult to make definite inferences regarding lake water levels.

From 10,500 to $9000 \mathrm{cal} \mathrm{yr} \mathrm{BP}$, the steppic vegetation evolved progressively (LPAZ 3; see Fig. 4) from Amaranthaceae-Chenopodiaceae steppes to grassland. The Poaceae values exceed $50 \%$ at the end of this phase (LPAZ 3). This herbaceous dynamic was recognized in the pioneering study carried out by Margalitadze (1977), but in the absence of absolute dating, an age between about 5000 and $3000 \mathrm{cal}$ yr BP was proposed. Such a pattern, characterized by the rise of Poaceae and the decline of Amaranthaceae-Chenopodiaceae, was also described for the
Lake Van sequence (Fig. 5) and dated between 11,500 and 9000 cal yr BP (Wick et al., 2003; Litt et al., 2009). The same pattern was also observed in other pollen records from the Near East: in Turkey (Eski Acigöl: Roberts et al., 2001) and in Iran (Lake Zeribar: Van Zeist and Bottema, 1977; Stevens et al., 2001; and Lake Urmia: Bottema, 1986). Interestingly, the Paravani pollen record does not display a "Poaceae phase" (Messager et al., 2013). This might be related to the very low SR (sedimentation rate) observed for the early Holocene in the first Paravani sequence studied (PAR 09-01). Some of the new cores, collected in other sites of Lake Paravani basin, yield thicker early Holocene deposits, in which pollen records display significant Poaceae values (more than 30\%) for the early Holocene period (work in progress). In the Nariani sequence, the very end of this phase is marked by a decline in grasses and a very slight expansion of trees (from 9500 to $9100 \mathrm{cal} \mathrm{yr} \mathrm{BP}$ ). Such a pattern, showing a moderate initial rise in AP values, is also recorded in the Black Sea core 22-GC3 (Fig. 5). In the Nariani record, this could reflect an initial tree expansion in lower altitude vegetation belts, perhaps even from the western part of the South Caucasus (by long-distance pollen transport). The end of this phase is marked by the decline of Myriophyllum and the beginning of the Cyperaceae expansion. This probably indicates a lowering of the lake level inducing the colonization of exposed shores by sedges. In such edaphic conditions, some hygrophytic species of Poaceae (i.e., Phragmites) could have grown and contributed to the Poaceae pollen increase we observed.

\section{Forested phase}

The onset of the forested phase, starting around $9000 \mathrm{cal} \mathrm{yr}$ $\mathrm{BP}$, is marked by a significant expansion of trees. Although the AP values rapidly reach $50 \%$, they never exceed $65 \%$ during the more forested phase (LPAZ 4). In the neighbouring Paravani pollen record, the AP values also increase rapidly but reach more than $80 \%$ (Messager et al., 2013). The question of over- or underrepresentation of trees in pollen records from the Javakheti highlands has already been addressed (Kvavadze, 1993; Connor, 2011; Messager et al., 2013), and the Nariani paleolake is likely to have been smaller than Paravani, thus probably limiting the "tree overrepresentation effect" seen in large lakes. In the Nariani sequence, the main trees undergoing expansion at the time are pines (Pinus), firs (Abies), and beeches (Fagus). The Abies and Fagus tree taxa do not currently grow in the Nariani watershed, but they are well developed in the Bakuriani area located only $10-20 \mathrm{~km}$ to the northwest (see Fig. 2). Considering the low representation of Abies in modern pollen rain on the Javakheti Plateau (Connor et al., 2004; Connor, 2011), its significant values in the Nariani record $(10 \%-30 \%)$ indicate that fir forests were probably well developed and could have expanded on the Javakheti Plateau at that time. Compared with the Paravani record, the more significant values for Fagus and Abies indicate the presence of higher-altitude vegetation belts in the Nariani area. 
The trees representing lower vegetation belts, such as oak (Quercus), elm (Ulmus), or hornbeam (Carpinus), are also recorded in Nariani, but in lower proportions. They probably reflect the midaltitude forest belt that developed on lower plateaus, such as the Tsalka Plateau (Connor, 2011). Just prior to 8000 cal yr BP, the tree cover decreased slightly to reach a phase of equilibrium between the different forest formations and the grassland. This situation lasted at least until 5000 cal yr BP (end of the sequence; Fig. 4). Among the herbaceous taxa, no sign of human impact has been detected, and the development of Cyperaceae in the upper part of the sequence probably reflects the filling of Lake Nariani.

\section{Deciphering the delayed forest expansion recorded in Nariani}

In the Nariani pollen record, the beginning of the Holocene is not characterized by the expansion of trees as observed in most of the pollen records from western, northern, and central Europe (Huntley and Birks, 1983; Watts et al., 1996). Steppes were still the preponderant vegetation type during the early Holocene, as observed in other paleoenvironmental records from southeastern Europe and the Near East (Van Zeist and Bottema, 1977; Bottema, 1986; Stefanova and Ammann, 2003; Wright et al., 2003; Djamali et al., 2008, 2010; Connor et al., 2013; Leroy et al., 2013, 2014). In the South Caucasus, this delay is well recorded in different sequences, such as those from Gomnis (Margalitadze, 1995), Paravani (Messager et al., 2013), Zarishat (Joannin et al., 2014), and Vanevan (Leroyer et al., 2016). Depending of the sequences studied in the South Caucasus, the afforestation event ranges from $9200 \mathrm{cal} \mathrm{yr} \mathrm{BP}$ (Nariani) to $8000 \mathrm{cal} \mathrm{yr} \mathrm{BP}$ (Zarishat: Joannin et al., 2014). However, one has to consider a relative synchronicity in these ages because of dating and age-depth model uncertainties. Different hypotheses have already been proposed to explain this pattern: (1) the time lag in tree migration from glacial tree refugia; (2) the impact of burning (Roberts, 2002; Turner et al., 2010); (3) a relatively dry early Holocene climate (Van Zeist and Bottema, 1991; Roberts and Wright, 1993; Stevens et al., 2001, 2006; Wright et al., 2003; Djamali et al., 2010); and (4) a negative feedback from the "Black Lake" preceding the filling of the Black Sea by Mediterranean waters (Leroy et al., 2013).

\section{The time lag in tree migration}

The delay in afforestation could be explained by a slow eastward postglacial migration of trees from their refugia. In the South Caucasus, the Colchis region (located in western Georgia, bordering the Black Sea) is considered to be the main glacial tree refugia (Shatilova and Ramishvili, 1990; Kvavadze et al., 1992; Connor and Kvavadze, 2008). According to different climatic model simulations (different ECHAM models), the eastern coast of the Black Sea and the southwestern coast of the Caspian Sea were highlighted as possible refugia for summer-green trees during the Last Glacial Maximum (Leroy and Arpe, 2007; Arpe et al., 2011).
This area is located only $150 \mathrm{~km}$ from the Javakheti Plateau. Of course, the Javakheti Plateau is separated from the refugia by mountains, but there are no high mountain barriers in this part of the Lesser Caucasus, and there are quite large valleys, which would have permitted the reexpansion of trees. The simultaneous expansion of the different tree taxa, recorded in both Nariani and Paravani, shows that as soon as regional climatic conditions were favorable on the Plateau, the trees were able to reach the Javakheti Plateau concurrently (Messager et al., 2013).

\section{The impact of early Holocene burning}

The role played by grassland burning, as a brake on the woodland expansion of the early Holocene, has already been investigated (Roberts, 2002; Turner et al., 2008, 2010). In the Eski Acigöl sequence (Anatolia), there is a positive correlation between grass pollen and microcharcoal frequency between 15,000 and $8000 \mathrm{cal} \mathrm{yr} \mathrm{BP,} \mathrm{"implying} \mathrm{that} \mathrm{summer}$ grass fires accounted for a significant part of the regional atmospheric charcoal flux" (Turner et al., 2008, p. 321). An increase in fire activity is also recorded for the early Holocene in the Lake Van sequence (Wick et al., 2003). Is this pattern due to wildfires or anthropic fires? The question of landscape management through deliberate burning by early Neolithic populations has been examined (Roberts, 2002; Turner et al., 2010). For the Javakheti Plateau, although charcoal analysis has not yet been undertaken on the Nariani and Paravani cores, regional fire signals reconstructed from Aligol (Connor, 2011) and Zarishat (Joannin et al., 2014) records may be considered. Situated on a neighbouring plateau (Tsalka region), the charcoal concentrations from Lake Aligol (Connor, 2011) remain very low until the late Chalcolithic (i.e., 5300-5000 cal yr BP). In Zarishat, there is no significant charcoal input before $5500 \mathrm{cal}$ yr BP. Therefore, these regional results do not reveal any fire impact during the time lag in forest expansion $(11,500-8000 \mathrm{cal} \mathrm{yr}$ BP). Nonetheless, charcoal analysis will be carried out on the Paravani and Nariani sequences in order to test the correlation between Poaceae and fire intensity. However, a potential impact because of early Neolithic fires is unlikely in this part of the South Caucasus because the oldest Neolithic sites identified so far date to $8000 \mathrm{cal} \mathrm{yr} \mathrm{BP}$ at the earliest (Hamon et al., 2016).

\section{The question of seasonality}

Despite the fact that Nariani and other regional pollen records indicate ongoing arid climatic conditions, geochemical and isotopic indicators from Lake Van (Lemcke and Sturm, 1997; Wick et al., 2003), Lake Eski Acigöl (Roberts et al., 2001; Jones et al., 2007), and Nar Gölü (Dean et al., 2015) in Turkey, show much higher water levels and/or lower salinities during the early Holocene. The hypothesis of higher precipitation is also supported by stalagmite records (Bar-Mathews et al., 1999; Fleitmann et al., 2009; Göktürk et al., 2011). These results suggest increasing annual 
precipitation during the early Holocene but do not necessarily contradict the pollen data. In fact, one of the key bioclimatic parameters that control the growth and development of tree populations is spring (and late spring) precipitation. So, although the annual precipitation might have increased during the early Holocene, the forest expansion was probably limited by low spring precipitation (lack of water during the growing season of trees). The "wet early Holocene" identified by means of lacustrine geochemical and isotopic indicators, as well as stalagmite records, could be the result of increased precipitation in winter and/or in fall (Brayshaw et al., 2011; Göktürk et al., 2011; Dean et al., 2015). The winter snowfalls may have melted during spring and summer, thereby generating higher lake stands.

The seasonality of precipitation may be one of the "keys" to understanding the regional ecological shift that occurred throughout the early Holocene, and this issue is the subject of much debate (Arz et al., 2003; Tzedakis, 2007; Rohling et al., 2009; Göktürk et al., 2011). For the Mediterranean basin, different scenarios, including the following, have been proposed for the period of sapropel deposition (between $\sim 9$ and 6 cal ka BP): (a) an increase in summer precipitation (Rohling et al., 2009) and (b) enhanced autumn/winter precipitation (Tzedakis, 2007). For the Black Sea basin, the Nariani pollen record tends to support the hypothesis of increasing autumn/ winter rainfall at the beginning of the Holocene, followed by a transition period marked by a slight increase in springsummer precipitation from 10,500 to $9000 \mathrm{cal} \mathrm{yr}$ BP, which is indicated by the replacement of AmaranthaceaeChenopodiaceae by Poaceae steppes. This hypothesis has already been proposed based on the expansion of Poaceae (Rossignol-Strick, 1995). These phases are finally followed by a marked increase in spring-summer rainfall beginning between 9000 and $8000 \mathrm{cal} \mathrm{yr} \mathrm{BP.} \mathrm{The} \mathrm{hypothesis} \mathrm{of}$ increasing spring rainfall has also been proposed on the basis of $\delta^{18} \mathrm{O}$ values from Zeribar Lake in western Iran (Stevens et al., 2001) and Lake Van in Turkey (Wick et al., 2003). For this region (Near East), the influence of the Indian summer monsoon has already been proposed to explain the shift from a Mediterranean-type climate to one dominated by spring precipitation, which would have favoured the expansion of deciduous oak forest just after the early Holocene (Djamali et al., 2010). In the Caucasus region, the climate reconstructions based on pollen data from Zarishat Fen, in Armenia, also support increasing spring rainfall after $8000 \mathrm{cal}$ yr BP (Joannin et al., 2014), but understanding the mechanisms controlling this climatic shift remains a challenge.

\section{The Black Sea influence}

In the Black Sea pollen records (Fig. 5), an abrupt increase in deciduous tree pollen is recorded between 9000 and $8000 \mathrm{cal}$ yr BP (Atanassova, 2005; Shumilovskikh et al., 2012; Filipova-Marinova et al., 2013). The $\delta^{18} \mathrm{O}$ signature recorded in Sofular stalagmites (Fig. 5) reflects the increasing input of Mediterranean water into the Black Sea (Badertscher et al., 2011). The opening of the Black Sea corridor led to the conversion of lacustrine waters to marine waters (Ryan et al., 1997; Bahr et al., 2006; Bardertscher et al., 2011). The emergence of a larger water body, which was marine in nature, in the Black Sea Basin, probably played a major role in determining the nature, quantity, and rhythm of rainfall in the neighbouring regions. Although the Black Sea effect on vegetation in the western South Caucasus is significant at the present time (Volodicheva, 2002), its role in the regional climatic mechanism during the early Holocene is not well understood (Göktürk et al., 2011).

The change in precipitation seasonality, as attested to by the Nariani and Paravani pollen records, is almost simultaneous with the process of Black Sea opening during the early Holocene. However, further palaeoecological and palaeoclimatic studies are required to clarify these complex relationships. Further east, in the Caspian Sea records, the period corresponding to the early Holocene (11,500-8400 cal yr BP) and characterized by a major regression (Ollivier et al., 2015, 2016), is marked by a shrub phase associated with low AP values (Leroy et al., 2013). This has been interpreted as the result of dry climatic conditions in which the two large water bodies (Caspian and Black Seas), filled by cold meltwater, had a negative feedback effect ("lake effect") by delaying warming (Leroy et al., 2013). It is worth noting the relative synchronicity (considering the ${ }^{14} \mathrm{C}$ uncertainties) of the end of the steppic phases between the Black Sea basin (9000-8200 cal yr BP, depending on the record) and the southern Caspian Sea basin $(8400 \mathrm{cal}$ yr BP). The effect of the Black Sea on the regional precipitation regimes, as well as its potential interactions with the monsoon mechanism (Djamali et al., 2010; Göktürk et al., 2011), need to be tested as part of future studies using experimental modeling.

\section{CONCLUSION}

Pollen data from the Nariani paleolake sediment core reveal significant environmental and climatic changes over the last 12,700 years. They indicate semidesert vegetation dominated by Amaranthaceae-Chenopodiaceae, associated with arid climatic conditions during the Younger Dryas and the beginning of the early Holocene. The Nariani record sheds new light on early Holocene vegetation history in the South Caucasus, as it reveals a significant "Poaceae phase" immediately following the Amaranthaceae-Chenopodiaceae semidesert. This transition phase indicates a relative increase in moisture during this period. However, this moisture increase does not appear sufficient for woodland expansion in the Lesser Caucasus at the altitude of Nariani. Between 9000 and $8500 \mathrm{cal}$ yr BP, the vegetation history is marked by a clear shift from open to forested vegetation. The chronology of forest expansion ( 3 millennia later than in western Eurasia) recorded in Nariani confirms the delay previously observed in the Paravani sequence and in other regional pollen records. The dry climate during the growing season favored steppe vegetation until 9000-8500 cal yr BP. The delay in forest expansion can be interpreted as being the result of variation in seasonal distributions of moisture (transition from an 
autumn-winter to a spring precipitation regime). The origin of the change in seasonality of precipitation is still open to debate, but the filling of the Black Sea, which occurred at that time, possibly played an essential role.

\section{ACKNOWLEDGMENTS}

This research was partly supported by the "GATES, Georgian Ancient Transcaucasia: Environments and Societies" LIA (International Associated Laboratory) project, founded by the French Environment and Ecology Institute (InEE, CNRS); the "Past and modern biodiversity" ATM program of the National Museum of Natural History (MNHN); and the ANR (National Research Agency)-12 JSH3-003-01 Orimil project, directed by E. Herrscher. Thanks to L. Perrin for his significant contribution to the fieldwork logistics. Thanks to P. Voinchet for supporting the first expedition at Nariani. Radiocarbon dates were provided by LMC14 Laboratory, Gif-sur-Yvette. We express our gratitude to Rhoda Allanic for correcting the language. Finally, we are grateful to Derek Booth, Robert Booth, and the two reviewers for their suggestions that greatly contributed to improving the paper.

\section{REFERENCES}

Arabuli, G., Kvavadze, El., Kikodze, D., Connor, S.E., Kvavadze, Er., Bagaturia, N., Murvanisze, M., Arabuli, T., 2008. The Krummholz beech woods of Mt. Tavkvetili (Javakheti Plateau, Southern Georgia) - a relict ecosystem. Proceedings of the Institute of Zoology 23, 194-213.

Arpe, K., Leroy, S.A.G., Mikolajewicz, U., 2011. A comparison of climate simulations for the last glacial maximum with three different versions of the ECHAM model and implications for summer-green tree refugia. Climate of the Past 7, 91-114.

Arz, H.W., Lamy, F., Patzold, J., Muller, P.J., Prins, M., 2003. Mediterranean moisture source for an early-Holocene humid period in the northern Red Sea. Science 300, 118-121.

Atanassova, J., 2005. Palaeoecological setting of the western Black Sea area during the last 15000 years. Holocene 15, 576-584.

Badertscher, S., Fleitmann, D., Cheng, H., Edwards, R.L., Göktürk, O.M., Zumbühl, A., Leuenberger, M., Tüysüz, O., 2011. Pleistocene water intrusions from the Mediterranean and Caspian seas into the Black Sea. Nature Geoscience 4, 236-239.

Bahr, A., Arz, H.W., Lamy, F., Wefer, G., 2006. Late glacial to Holocene paleoenvironmental evolution of the Black Sea, reconstructed with stable oxygen isotope records obtained on ostracod shells. Earth and Planetary Science Letters 241, 863-875.

Bar-Matthews, M., Ayalon, A., Kaufman, A., Wasserburg, G.J., 1999. The Eastern Mediterranean paleoclimate as a reflection of regional events: Soreq cave, Israel. Earth and Planetary Science Letters 166, 85-95.

Beug, H.-J., 2004. Leitfaden der Pollenbestimmung für Mitteleuropa und angrenzende Gebiete. Pfeil, Munich.

Birks, H.J.B., Birks, H.H., 1980. Quaternary Palaeoecology, Edward Arnold, London.

Blaauw, M., 2010. Methods and code for 'classical' age-modelling of radiocarbon sequences. Quaternary Geochronology 5, $512-518$.
Bohn, U., Gollub, G., Hettwer, C., 2000. Karte der natürlichen Vegetation Europas. Bundesamt für Naturschutz, Bonn, Germany.

Bottema, S., 1986. A late Quaternary pollen diagram from Lake Urmia (northwestern Iran). Review of Palaeobotany and Palynology 47, 241-261.

Bottema, S., 1995. The Younger Dryas in the Eastern Mediterranean. Quaternary Science Reviews 14, 883-891.

Brayshaw, D.J., Rambeau, C.M.C., Smith, S.J., 2011. Changes in Mediterranean climate during the Holocene: insights from global and regional climate modelling. Holocene $21,15-31$.

Connor, S.E., 2011. A Promethean Legacy: Late Quaternary Vegetation History of Southern Georgia, the Caucasus. Peeters, Leuven, Belgium.

Connor, S.E., Kvavadze, E.V., 2008. Modelling late Quaternary changes in plant distribution, vegetation and climate using pollen data from Georgia, Caucasus. Journal of Biogeography 36, 529-545.

Connor, S.E., Ross, S.A., Sobotkova, A., Herries, A.I.R., Mooney, S.D., Longford, C., Iliev, I., 2013. Environmental conditions in the SE Balkans sine the Last Glacial Maximum and their influence on the spread of agriculture into Europe. Quaternary Science Reviews 68, 200-215.

Connor, S.E., Sagona, A., 2007. Environment and society in the late prehistory of Southern Georgia, Caucasus. In: Lyonnet, B. (Ed.), Les cultures du Caucase (VIe-IIIe millénaires avant notre ère): Leurs relations avec le Proche-Orient. Editions Recherche sur les Civilisations. CNRS Editions, Paris, pp. 21-36.

Connor, S.E., Thomas, I., Kvavadze, E., Arabuli, G.J., Avakov, G., Sagona, A., 2004. A survey modern pollen and vegetation along an altitudinal transect in southern Georgia, Caucasus region. Review of Palaeobotany and Palynology 129, 229-250.

Dean, J.R., Jones, M.D., Leng, M.J., Noble, S.R., Metcalfe, S.E., Sloane, H.J., Sahy, D., Eastwood, W.J., Roberts, C.N., 2015. Eastern Mediterranean hydroclimate over the late glacial and Holocene, reconstructed from the sediments of Nar lake, central Turkey, using stable isotopes and carbonate mineralogy. Quaternary Science Reviews 124, 162-174.

de Klerk, P., Haberl, A., Kaffke, A., Krebs, M., Matchutadze, I., Minke, M., Schulz, J., Joosten, H., 2009. Vegetation history and environmental development since ca $6000 \mathrm{cal} \mathrm{yr} \mathrm{BP}$ in and around Ispani 2 (Kolkheti lowlands, Georgia). Quaternary Science Reviews 28, 890-910.

Djamali, M., Akhani, H., Andrieu-Ponel, V., Braconnot, P., Brewer, S., de Beaulieu, J.-L., Fleitmann, D., et al., 2010. Indian summer monsoon variations could have affected the earlyHolocene woodland expansion in the Near East. Holocene 20, $813-820$

Djamali, M., de Beaulieu, J.-L., Shah-hosseini, M., Andrieu-Ponel, V., Ponel, P., Amini, A., Akhani, H., et al., 2008. A late Pleistocene long pollen record from Lake Urmia, NW Iran. Quaternary Research 69, 413-420.

Fægri, K., Iversen, J., 1989. Textbook of pollen analysis (revised by Fægri, K., Kaland, P.E. and Krzywinski, K.). John Wiley and Sons.

Filipova-Marinova, M., Pavlov, D., Coolen, M., Giosan, L., 2013. First high-resolution marinopalynological stratigraphy of Late Quaternary sediments from the central part of the Bulgarian Black Sea area. Quaternary International 293, 170-183.

Fleitmann, D., Cheng, H., Badertscher, S., Edwards, R.L., Mudelsee, M., Göktürk, O.M., Fankhauser, A., et al., 2009. 
Timing and climatic impact of Greenland interstadials recorded in stalagmites from northern Turkey. Geophysical Research Letters 36, L19707. http://dx.doi.org/10.1029/2009GL040050.

Girard, M., Renault-Miskovsky, J., 1969. Nouvelles techniques de préparation en palynologie, appliquées à trois sédiments du Quaternaire final de l'Abri Cornille (Istres, Bouches-du-Rhone). Bulletin de l'Association Française pour l'Étude du Quaternaire 6, 275-284.

Goeury, C., 1997. GpalWin: gestion, traitement et représentation de la paléoécologie. XVe Symposium de l'APLF, Lyon, France, p. 31.

Goeury, C., Beaulieu, J.L. de, 1979. A propos de la concentration du pollen à l'aide de la liqueur de Thoulet dans les sédiments minéraux. Pollen Spores 21, 239-251.

Göktürk, O.M., Fleitmann, D., Badertscher, S., Cheng, H., Edwards, R.L., Leuenberger, M., Fankhauser, A., Tüysüz, O., Kramers, J., 2011. Climate on the Southern Black Sea coast during the Holocene: implications from the Sofular Cave record. Quaternary Science Reviews 30, 2433-2445.

Grimm, E., 1987. CONISS: a Fortran 77 Program for stratigraphically constraint cluster analysis by the method of incremental squares. Computers and Geosciences 13, 13-35.

Hamon, C., Jalabadze, M., Agapishvili, T., Baudouin, E., Koridze, I., Messager, E., 2016. Gadachrili Gora: Architecture and organisation of a Neolithic settlement in the middle Kura Valley (6th millennium BC, Georgia). Quaternary International 395, 154-169.

Heiri, O., Lotter, A.F., Lemcke, G., 2001. Loss on ignition as a method for estimating organic and carbonate content in sediments: reproducibility and comparability of results. Journal of Paleolimnology 25, 101-110.

Huntley, B., Birks, H.J.B., 1983. An Atlas of Past and Present Pollen Maps for Europe: 0-13000 years ago. Cambridge University Press, Cambridge.

Joannin, S., Ali, A.A., Ollivier, V., Roiron, P., Peyron, O., Chevaux, S., Nahapetyan, S., Tozalakyan, P., Karakhanyan, A., Chataigner, C., 2014. Vegetation, fire and climate history of the Lesser Caucasus: a new Holocene record from Zarishat fen (Armenia). Journal of Quaternary Science 29, 70-82.

Jones, M.D., Roberts, C.N., Leng, M.J., 2007. Quantifying climatic change through the last glacial-interglacial transition based on lake isotope palaeohydrology from central Turkey. Quaternary Research 67, 463-473.

Kvavadze, E.V., 1993. On the interpretation of subfossil spore-pollen spectra in the mountains. Acta Palaeobotanica 33, 347-360.

Kvavadze, E.V., Bukreeva, G.F., Rukhadze, L.P., 1992. Komp'iuternaia Tekhnologia Rekonstruktsii Paleogeograficheskikh Rekonstruksii V Gorakh (na primere golotsena Abkhazii). Metsniereba, Tbilisi, Georgia.

Kvavadze, E.V., Connor, S.E., 2005. Zelkova carpinifolia (Pallas) K. Koch in Holocene sediments of Georgia - an indicator of climatic optima. Review of Palaeobotany and Palynology 133, 69-89.

Lebedev, V.A., Bubnov, S.N., Dudauri, O.Z., Vashakidze, G.T., 2008. Geochronology of Pliocene volcanism in the Dzhavakheti Highland (the Lesser Caucasus). Part 2: Eastern part of the Dzhavakheti Highland. Regional geological correlation. Stratigraphy and Geological Correlation 16, 553-574.

Lemcke, G., Sturm, M., 1997. $\delta^{18} \mathrm{O}$ and trace element measurements as proxy for the reconstruction of climate changes at Lake Van (Turkey): preliminary results. In: Dalfes, H.N., Kukla, G., Weiss, H.
(Eds.), Third Millennium BC Climate Change and Old World Collapse. NATO ASI Series 49. Springer, Berlin, pp. 653-678.

Leroy, S.A.G., Arpe, K., 2007. Glacial refugia for summer-green trees in Europe and south-west Asia as proposed by ECHAM3 time-slice atmospheric model simulations. Journal of Biogeography 34, 2115-2128.

Leroy, S.A.G., Lopez-Merino, L., Tudryn, A., Chalie, F., Gasse, F., 2014. Late Pleistocene and Holocene palaeoenvironments in and around the middle Caspian basin as reconstructed from a deep-sea core. Quaternary Science Reviews 101, 91-110.

Leroy, S.A.G., Tudryn, A., Chalie, F., Lopez-Merino, L., Gasse, F., 2013. From the Allerød to the mid-Holocene: palynological evidence from the south basin of the Caspian Sea. Quaternary Science Reviews 78, 77-97.

Leroyer, C., Joannin, S., Aoustin, D., Ali, A.A., Peyron, O., Ollivier, V., Tozalakyan, P., Karakhanyan, A., Jude, F., 2016. Mid Holocene vegetation reconstruction from Vanevan peat (south-eastern shore of Lake Sevan, Armenia). Quaternary International 395, 5-18.

Litt, T., Krastel, S., Sturm, M., Kipfer, R., Örcen, S., Heumann, G., Franz, S.O., Ülgen, U. B., Niessen, F., 2009. 'PALEOVAN', International Continental Scientific Drilling Program (ICDP): site survey results and perspectives. Quaternary Science Reviews $28,1555-1567$.

Litt, T., Pickarski, N., Heumann, G., Stockhecke, M., Tzedakis, P.C., 2014. A 600,000 year long continental pollen record from Lake Van, eastern Anatolia (Turkey). Quaternary Science Reviews 104, 30-41.

Margalitadze, N.A., 1971. The history of forests of the northwestern part of the Trialeti Range in Holocene according to pollen analysis. Journal of Palynology (India) 7, 69-75.

Margalitadze, N.A., 1977. Istoriia rastitel'nosti Dzhavakhetskogo Nagor'ia i Tsalkinskogo Plato v Golotsene [In Russian]. In: Tumadzhanov, I.I. (Ed.) Palinologicheskie issledovania $v$ Gruzii. Metsniereba, Tbilisi, Georgia, pp. 124-147.

Margalitadze, N.A., 1995. Istoriia golotsenovoi rastitel'nosti Gruzii [In Russian]. Metsniereba, Tbilisi, Georgia.

Matcharashvili, I., Arabuli, G., Darchiashvili, G., Gorgadze, G., 2004. Javakheti Wetlands: Biodiversity and Conservation [In Georgian and English]. NACRES, Tbilisi, Georgia.

Messager, E., Belmecheri, S., von Grafenstein, U., Nomade, S., Ollivier, V., Voinchet, P., Puaud, S., et al., 2013. Late Quaternary record of the vegetation and catchment-related changes from Lake Paravani (Javakheti, South Caucasus). Quaternary Science Reviews 77, 125-140.

Nakhutsrishvili, G.S., 1999. The vegetation of Georgia (Caucasus). Braun-Blanquetia 15, 1-68.

Nomade, S., Scao, V., Guillou, H., Messager, E., Mgeladze, A., Voinchet, P., Renne, P.R., et al., 2016. New ${ }^{40} \mathrm{Ar} /{ }^{39} \mathrm{Ar}$, unspiked $\mathrm{K} / \mathrm{Ar}$ and geochemical constraints on the Pleistocene magmatism of the Samtskhe-Javakheti highlands (Republic of Georgia). Quaternary International 395, 45-59.

Ollivier, V., Fontugne, M., Lyonnet, B., 2015. Geomorphic response and ${ }^{14} \mathrm{C}$ chronology of base-level changes induced by Late Quaternary Caspian Sea mobility (middle Kura Valley, Azerbaijan). Geomorphology 230, 109-124.

Ollivier, V., Fontugne, M., Lyonnet, B., Chataigner, C., 2016. Base level changes, river avulsions and Holocene human mode of occupations in the Caspian Sea area (middle Kura valley, South Caucasus). Quaternary International 395, 79-94.

Rasmussen, S.O., Andersen, K.K., Svensson, A., Steffensen, J.P., Vinther, B.M., Clausen, H.B., Siggaard-Andersen, M.-L., et al., 
2006. A new Greenland ice core chronology for the last glacial termination. Journal of Geophysical Research: Atmospheres 111, D06102. http://dx.doi.org/10.1029/2005JD006079.

Reille, M., 1992. Pollen et Spores d'Europe et d'Afrique du Nord. Laboratoire de Botanique Historique et Palynologie, Marseille, France.

Reimer, P.J., Bard, E., Bayliss, A., Beck, J.W., Blackwell, P.G., Bronk Ramsey, C., Buck, C.E., et al., 2013. IntCal13 and Marine13 radiocarbon age calibration curves $0-50,000$ years cal BP. Radiocarbon 55, 1869-1887.

Roberts, N., 2002. Did prehistoric landscape management retard the post-glacial spread of woodland in Southwest Asia? Antiquity 76, 1002-1010.

Roberts, N., Reed, J.M., Leng, M.J., Kuzucuoğlu, C., Fontugne, M., Bertaux, J., Woldring, H., et al., 2001. The tempo of Holocene climatic change in the eastern Mediterranean region: new high-resolution craterlake sediment data from central Turkey. Holocene 11, 721-736.

Roberts, N., Wright, H.E., Jr., 1993. Vegetational, lake-level and climatic history of the Near East and Southwest Asia. In: Wright, H.E. Jr., Kutzbach, J.E., Webb, T. III, Ruddiman, W.F., StreetPerrott, F.A., Bartlein, P.J. (Eds). Global Climates Since the Last Glacial Maximum. University of Minnesota Press, 194-220.

Rohling, E.J., Abu-Zied, R., Casford, J.L.S., Hayes, A., Hoogakker, B.A.A., 2009. The marine environment: present and past. In: Woodward, J.C. (Ed.), The Physical Geography of the Mediterranean. Oxford University Press, Oxford, pp. 33-67.

Rossignol-Strick, M., 1995. Sea-land correlation of pollen records in the Eastern Mediterranean for the glacial-interglacial transition: biostratigraphy versus radiometric time-scale. Quaternary Science Reviews 14, 293-315.

Ryan, W.B.F., Pitman, W.C., Major, C.O., Shimkus, K., Moskalenko, V., Jones, G.A., Dimitrov, P., Gorür, N., Sakinç, M., Yüce, H., 1997. An abrupt drowning of the Black Sea shelf. Marine Geology 138, 119-126.

Shatilova, I., Ramishvili, Sh., 1990. Materiali po istorii flori I rastitel'nosti Gruzii (in Russian), Metsniereba, Tbilissi, Georgia.

Shumilovskikh, L., Tarasov, P., Arz, H.W., Fleitmann, D., Marret, F., Nowaczyk, N., Plessen, B., Schlütz, F., Behling, H., 2012. Vegetation and environmental dynamics in the southern Black Sea region since $18 \mathrm{kyr}$ BP derived from the marine core 22-GC3. Palaeogeography, Palaeoclimatology, Palaeoecology 337-338, 177-193.

Stefanova, I., Ammann, B., 2003. Late-glacial and Holocene vegetation belts in the Pirin Mountains (southwestern Bulgaria). Holocene 13, 97-107.

Stevens, L.R., Ito, E., Schwalb, A., Wright, H.E., Jr., 2006. Timing of atmospheric precipitation in the Zagros Mountains inferred from a multi-proxy record from Lake Mirabad, Iran. Quaternary Research 66, 494-500.

Stevens, L.R., Wright, H.E., Jr., Ito, E., 2001. Proposed changes in seasonality of climate during the Lateglacial and Holocene at Lake Zeribar, Iran. Holocene 11, 747-755.

Svensson, A., Andersen, K.K., Bigler, M., Clausen, H.B., Dahl-Jensen, D., Davies, S.M., Johnsen, S.J., et al., 2006. The Greenland Ice Core Chronology 2005, 15-42 ka. Part 2: comparison to other records. Quaternary Science Reviews 25, 3258-3267.

Turner, R., Roberts, N., Eastwood, W.J., Jenkins, E., Rosen, A., 2010. Fire, climate and the origins of agriculture: micro-charcoal records of biomass burning during the last glacial-interglacial transition in Southwest Asia. Journal of Quaternary Science 25, 371-386.

Turner, R., Roberts, N., Jones, M.D., 2008. Climatic pacing of Mediterranean fire histories from lake sedimentary microcharcoal. Global and Planetary Change 63, 317-324.

Tzedakis, P.C., 2007. Seven ambiguities in the Mediterranean palaeoenvironmental narrative. Quaternary Science Reviews 26, 2042-2066.

Van Zeist, W., Bottema, S., 1977. Palynological investigations in western Iran. Palaeohistoria 19, 19-85.

Van Zeist, W., Bottema, S., 1991. Late Quaternary Vegetation of the Near East. Beihefte zum Tübinger Atlas des Vorderen Orients, Reihe A18. L. Reichert, Wiesbaden, Germany.

Volodicheva, N., 2002. The Caucasus. In: Shahgedanova M. (Ed.), The Physical Geography of Northern Eurasia. Oxford University Press, Oxford, pp. 350-376.

Von Grafenstein, U., Erlenkeuser, H., Brauer, A., Jouzel, J., Johnsen, S.J., 1999. A mid-European decadal isotope-climate record from 15,500 to 5000 years B.P. Science 284, 1654-1657.

Watts, W.A., Allen, J.R.M., Huntley, B., Fritz, S.C., 1996. Vegetation history and climate of the last 15,000 years at Laghi di Monticchio, southern Italy. Quaternary Science Reviews 15, 113-132.

Wick, L., 2000. Vegetational response to climatic changes recorded in Swiss Late Glacial lake sediments. Palaeogeography, Palaeoclimatology, Palaeoecology 159, 231-250.

Wick, L., Lemcke, G., Sturm, M., 2003. Evidence of Lateglacial and Holocene climatic change and human impact in eastern Anatolia: high-resolution pollen, charcoal, isotopic and geochemical records from the laminated sediments of Lake Van, Turkey. Holocene 13, 665-675.

Wright, H.E., Jr., Ammann, B., Stefanova, I., Atanassova, J., Margalitadze, N., Wick, L., Blyakharchuk, T., 2003. Lateglacial and early-Holocene dry climates from the Balkan peninsula to southern Siberia. In: Tonkov, S. (Ed.), Aspects of Palynology and Palaeoecology. Pensoft, Sofia, Bulgaria, pp. 127-136. 